Brief report

\title{
Toll-Like Receptor 2 R753Q Polymorphisms Are Associated With an Increased Risk of Infective Endocarditis
}

\author{
Juan Bustamante, ${ }^{\mathrm{a}, *}$ Eduardo Tamayo, ${ }^{\mathrm{b}}$ Santiago Flórez, ${ }^{\mathrm{a}}$ Juan J. Telleria, ${ }^{\mathrm{c}}$ Elena Bustamante, ${ }^{\mathrm{b}}$ \\ Javier López, ${ }^{\mathrm{d}}$ J. Alberto San Román, ${ }^{\mathrm{d}}$ and F. Javier Álvarez ${ }^{\mathrm{e}}$ \\ a Servicio de Cirugía Cardiaca, Instituto de Ciencias del Corazón (ICICOR), Hospital Clínico Universitario de Valladolid, Valladolid, Spain \\ ${ }^{\mathrm{b}}$ Servicio de Anestesiología y Cuidados Críticos, Hospital Clínico Universitario de Valladolid, Valladolid, Spain \\ ${ }^{\mathrm{c}}$ Instituto de Biología y Genética Molecular (IBGM/CSIC), Universidad de Valladolid, Valladolid, Spain \\ d Servicio de Cardiología, Instituto de Ciencias del Corazón (ICICOR), Hospital Clínico Universitario de Valladolid, Valladolid, Spain \\ e Departamento de Farmacología y Terapéutica, Facultad de Medicina, Universidad de Valladolid, Valladolid, Spain
}

Article history:

Received 20 December 2010

Accepted 20 February 2011

Available online 23 July 2011

\section{Keywords:}

Innate immunity

Single nucleotide polymorphism

Toll-like receptor 2

Infective endocarditis

\begin{abstract}
A B S T R A C T
The ability to respond to the ligands of toll-like receptors (TLR) could be affected by single nucleotide polymorphisms in TLR codifying genes. The influence of the polymorphisms TLR2 (R753Q R677W), TLR4 (D299G, T399I) and CD14 (C-159T) was consecutively studied in 65 patients with infective endocarditis. The control group $(n=66)$ consisted of healthy volunteers. All the polymorphisms were genotyped by means of restriction analysis after their amplification. An association between endocarditis and variants of TLR2 R753Q $(P<.001)$ was observed, but no association with other polymorphisms was found. The TLR2 R753Q co-dominant (odds ratio=13.33), recessive (odds ratio=9.12) and dominant (odds ratio=3.65) genotypes showed a positive association with the infective endocarditis phenotype. The polymorphism TLR2 R753Q was associated with a greater susceptibility towards the development of infective endocarditis. Further studies are required to validate these results and identify other genetic risk factors.
\end{abstract}

๑ 2011 Sociedad Española de Cardiología. Published by Elsevier España, S.L. All rights reserved.

El polimorfismo $\mathrm{R} 753 \mathrm{Q}$ del toll-like receptor 2 se asocia a un aumento en el riesgo de sufrir endocarditis infecciosa

RES U M E N

La capacidad para responder a los ligandos de toll-like receptors (TLR) puede verse afectada por polimorfismos de un solo nucleótido en genes que codifican TLR. Estudiamos la influencia de los polimorfismos TLR2 (R753Q, R677W), TLR4 (D299G, T399I) y CD14 (C-159T) en 65 pacientes consecutivos con endocarditis infecciosa. El grupo control $(n=66)$ estuvo formado por voluntarios sanos. Todos los polimorfismos fueron genotipados mediante análisis de restricción después de su amplificación. Se observó asociación de endocarditis con variantes de TLR2 R753Q ( $p<0,001)$ y no se encontró asociación con otros polimorfismos. Los genotipos TLR2 R753Q, codominantes (odds ratio $=13,33$ ), recesivo (odds ratio $=9,12$ ) y dominantes (odds ratio $=3,65$ ) mostraron asociación positiva con el fenotipo de endocarditis infecciosa. El polimorfismo TLR2 R753Q se asoció a una mayor susceptibilidad a sufrir endocarditis infecciosa. Son necesarios futuros estudios para validar estos resultados e identificar otros factores genéticos de riesgo.

(c) 2011 Sociedad Española de Cardiología. Publicado por Elsevier España, S.L. Todos los derechos reservados.

\section{INTRODUCTION}

The annual incidence of endocarditis is between 15 and 60 cases per million. ${ }^{1,2}$ The prognosis is poor and has remained steady over the last 4 decades. $^{2}$ Even with antibiotic therapy, the mortality rate is more than $30 \%$ in most studies, and may be as high as $70 \%$ among certain high-risk populations. ${ }^{2}$ The pathogenic mechanism by which infection of the endocardium develops is multifactorial. However, hereditary and immune factors may also contribute to its development. ${ }^{1,3}$

\footnotetext{
* Corresponding author: Servicio de Cirugía Cardiaca, Instituto de Ciencias del Corazón (ICICOR), Hospital Clínico Universitario de Valladolid, Ramón y Cajal 3, 47005 Valladolid, Spain.

E-mail address: jbustamantemunguira@gmail.com (J. Bustamante).
}

The toll-like receptors (TLRs) are involved in the innate immune system. To date, 11 TLRs have been identified that recognize distinct pathogen-associated molecular patterns that have been evolutionarily conserved in specific classes of microbes. These antigens include cell wall components of Gram-positive (bacterial lipoproteins and lipoteichoic acids, detected by TLR2) and Gramnegative (lipopolysaccharide [LPS], detected by TLR4) bacteria. Recognition of LPS involves an LPS receptor complex, of which CD14 and the TLR4 are important components. ${ }^{4}$

Data suggests that the ability of certain individuals to respond properly to TLR ligands may be impaired by single nucleotide polymorphisms (SNPs) within TLR genes, resulting in an altered susceptibility to infection or inflammation. ${ }^{5}$ Polymorphisms of the TLR2 R753Q gene have been linked to variations in responses to staphylococcus ${ }^{6}$ and polymorphisms of $\mathrm{R} 677 \mathrm{~W}$ are associated 
with an increased susceptibility to leprosy and tuberculosis in Asian populations. ${ }^{7}$ Two common mutations in the TLR4 gene have been described, TLR4 D299G and T399I. These mutations are reportedly linked to an increased risk of Gram-negative bacterial infections and septic shock. ${ }^{4,8} \mathrm{~A}$ polymorphism in the promoter region of the CD14 gene is associated with an increase in prevalence of Gram-negative bacterial infection. ${ }^{9}$

We hypothesized that polymorphisms in the genes of these innate immune receptors are associated with an increase in the prevalence of infective endocarditis. Here, we examined the frequency of the TLR2 (R753Q, R677W), TLR4 (D299G, T399I), and CD14 (C-159T) polymorphisms in patients with infective endocarditis and in healthy controls.

\section{METHODS}

\section{Patients and Controls}

Sixty-five patients (57 men, 8 women; mean \pm standard deviation age $63.7 \pm 11.9$ years, range $32-85$ years) diagnosed consecutively with infective endocarditis according to the Duke criteria were studied from December 2005 to December 2008 (flow inclusion of patients: 2006, 22 patients; 2007, 17; 2008, 26). The control group $(n=66)$ included healthy blood donors ( 55 men, 11 women; age $61.7 \pm 10.2$ years, range $32-79$ years). Patients and controls were members of a homogeneous population, all Caucasian and residents of the same region (Castilla y León, Spain). Each participant gave informed consent for the study, which was approved by the hospital's research committee.

\section{Genomic DNA Preparation and Quantization}

Two milliliters of whole blood samples were collected in ethylenediaminetetraacetic acid-coated tubes by standard venipuncture method. Genomic DNA was extracted from whole blood samples using the MagNA Pure Compact Nucleic Acid Isolation Kit I (Roche, Mannheim, Germany) following the manufacturer's instructions.

\section{Analysis of Polymorphisms in Genes}

All polymorphisms were genotyped by restriction analysis after polymerase chain reaction (PCR) amplification. Thirty-five cycles of PCR were performed on a thermal cycler (GeneAmp9700; Perkin-Elmer Cetus, Norwalk, Connecticut, United States). Primers were synthesized (VWR International Eurolab, Barcelona, Spain). The PCR reaction consisted of 50 ng DNA, 10 pm of each primer, $10 \mu \mathrm{l}$ PCR master mix (Promega, Madison, Wisconsin, United States) and up to $20 \mu$ l water.

TLR2 p.R677W (rs5743706) PCR primers were 5'CAATCCCCCCTTCAAGTTG- $3^{\prime}$ and 5'-CAGTTCATACTTGCACCACTC- $3^{\prime}$. The cycle program consisted of $94^{\circ} \mathrm{C}$ for $30 \mathrm{~s}, 58^{\circ} \mathrm{C}$ for $30 \mathrm{~s}$, and $72{ }^{\circ} \mathrm{C}$ for $30 \mathrm{~s}$. Ssil (Fermentas, Burlington, Canada).

TLR2 p.R753Q (rs5743708) PCR primers were 5'-GAAGAGAACAATGATGCTGCCATTC $-3^{\prime}$ and 5'CTAGGACTTTATCGCAGCTCTC $-3^{\prime}$. The cycle program consisted of $94{ }^{\circ} \mathrm{C}$ for $30 \mathrm{~s}, 49{ }^{\circ} \mathrm{C}$ for $30 \mathrm{~s}$, and $72{ }^{\circ} \mathrm{C}$ for $30 \mathrm{~s}$. Ssil (Fermentas, Burlington, Canada) (Fig. 1).

TLR4 p.D299G (rs4986790) PCR primers were 5'-ACTTAGACTACTACCTCGGTG-3' and 5'-GATTTGAGTTTCAATGTGGGAAAC-3'. The cycle program consisted of $94{ }^{\circ} \mathrm{C}$ for $30 \mathrm{~s}, 53{ }^{\circ} \mathrm{C}$ for $30 \mathrm{~s}$, and $72{ }^{\circ} \mathrm{C}$ for $30 \mathrm{~s}$. HphI (Fermentas, Burlington, Canada).

TLR4 p.T399I (rs4986791). PCR primers were 5'-TCTCAAAGTGATTTTGGGACGA-3 and 5'-GTTCTCAAAGTGATTTTGGGAATG-3'.

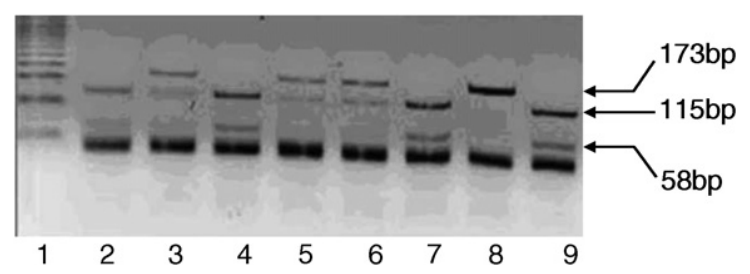

Figure 1. Electrophoretic migration of the toll-like receptor 2p.R753Q polymorphism.

The cycle program consisted of $94{ }^{\circ} \mathrm{C}$ for $30 \mathrm{~s}, 56{ }^{\circ} \mathrm{C}$ for $30 \mathrm{~s}$, and $72{ }^{\circ} \mathrm{C}$ for $30 \mathrm{~s}$. Mbol (Fermentas, Burlington, Canada).

CD14 c.-159C $>\mathrm{T}$ (rs2569190) PCR primers were $5^{\prime}$-TCACCTCCCCACCTCTCTT- $3^{\prime}$ and 5'-CCTGCAGAATCCTTCCTGTT- $3^{\prime}$. The cycle program consisted of $94{ }^{\circ} \mathrm{C}$ for $30 \mathrm{~s}, 59{ }^{\circ} \mathrm{C}$ for $30 \mathrm{~s}$, and $72{ }^{\circ} \mathrm{C}$ for 30 s. HaeIII (Roche, Mannheim, Germany).

\section{Statistical Analysis}

All statistical analyses were performed using SPSS Inc. version 15.0 (SPSS Inc., Chicago, Illinois, United States). Genotype (TLR2 R677W, TLR2 R753Q, TLR4 D299G, TLR4 T399I, and C-159T CD14) distribution was tested with Hardy-Weinberg equilibrium in patient and control groups. ${ }^{10}$ Student's t-test was used for the comparison of numeric variables within groups and the Pearson correlation test for the correlation of numeric variables. The $\chi^{2}$ test and Fisher's exact test (when appropriate) were used for comparison of groups. The data were expressed as mean \pm standard deviation, and statistical significance was accepted as a $P$-value $\leq .05$.

Logistic regression was used to estimate the effect of TLR2 R753Q genotypes on the odds of a patient having the phenotype for infective endocarditis under three genetic models (recessive, co-dominant, and dominant), as has been done previously. ${ }^{11}$

\section{RESULTS}

Endocarditis was of a community origin in 44 (67.7\%), a prior cardiopathy was detected in 39 (60\%), significant risk factor was identified in 31 (47.7\%), and predisposing diseases as follows: diabetes mellitus 12 (18.5\%), alcoholism $6(9.2 \%)$, cancer 4 (6.1\%), chronic renal failure $3(4.6 \%)$, chronic obstructive pulmonary disease 6 (9.2\%). Gram-positive bacteria were detected as a causative agent in 50 (76.9\%) patients (46.1\% Staphylococcus and $30.8 \%$ Streptococcus), while Gram-negative bacteria were the etiologic agent in $5(7.7 \%)$ patients. No causative agent was isolated in 9 (13.8\%) patients and 39 patients (60\%) needed surgical treatment and the hospital mortality rate was $30.8 \%(n=20)$.

\section{Distribution of Genotypes and Allele Frequencies in Patients and Control Group}

In the analysis of genes (Table 1), significant associations with infective endocarditis were seen for TLR2 R753Q for both the genotype $(P=.001)$ (Fig. 2$)$ and the allele variants $(P=.0001)$. No association was found with other polymorphisms. The genotype and allele frequencies of the TLR2 R753Q polymorphism were similar to frequencies reported from other available Caucasian data.

Further analyses were undertaken, using logistic regression to evaluate the significant TLR2 R753Q variants, 3 genetic models to test for the effect of the higher-risk genotype compared with the lowest-risk genotype, and the odds of having the infective 
Table 1

Distribution of Toll-Like Receptor 2, 4 and CD14 Gene Polymorphisms in Endocarditis Patients and Controls

\begin{tabular}{|c|c|c|c|c|c|c|c|c|c|c|c|}
\hline $\begin{array}{l}\text { Gene } \\
\text { polymorphism }\end{array}$ & $\begin{array}{l}\text { Genotype } \\
\text { frequencies }\end{array}$ & $\begin{array}{l}\text { Endocarditis } \\
\mathrm{n}=65\end{array}$ & $\begin{array}{l}\text { Controls } \\
\mathrm{n}=66\end{array}$ & $\begin{array}{l}\text { Pearson } \\
\chi^{2} 2\end{array}$ & $P$-value & $\begin{array}{l}\text { Allele } \\
\text { frequencies }\end{array}$ & Endocarditis & Controls & OR $(95 \% \mathrm{CI})$ & $\begin{array}{l}\text { Pearson } \\
\chi^{2}{ }^{2}\end{array}$ & $P$-value \\
\hline \multicolumn{12}{|l|}{ TLR2 R677W } \\
\hline & $\mathrm{CC}$ & $36(55.4)$ & $41(62.2)$ & & & $\mathrm{C}$ & $95(73.1)$ & $104(78.8)$ & $0.731[0.413-1.291]$ & 1.1696 & .2795 \\
\hline & TC & $23(35.4)$ & $22(33.3)$ & 1.3393 & .5119 & $\mathrm{~T}$ & 35 (26.9) & $28(21.2)$ & & & \\
\hline & TT & $6(9.2)$ & $3(4.5)$ & & & & & & & & \\
\hline \multicolumn{12}{|l|}{ TLR2 R753Q } \\
\hline & $\mathrm{R} / \mathrm{R}$ & $30(46.1)$ & $50(75.8)$ & & & $\mathrm{R}$ & 87 (66.9) & $115(87.1)$ & $0.299[0.16-0.56]$ & 15.1335 & .0001 \\
\hline & $\mathrm{R} / \mathrm{Q}$ & $27(41.6)$ & $15(22.7)$ & 13.8662 & .001 & Q & $43(33.1)$ & $17(12.9)$ & & & \\
\hline & $\mathrm{Q} / \mathrm{Q}$ & $8(12.3)$ & $1(1.5)$ & & & & & & & & \\
\hline \multicolumn{12}{|l|}{ TLR4 D299G } \\
\hline & $\mathrm{D} / \mathrm{D}$ & $53(81.5)$ & $60(90.9)$ & & & $\mathrm{D}$ & $117(90)$ & $125(94.7)$ & 0.504 [0.194-1.307] & 2.049 & .152 \\
\hline & $\mathrm{D} / \mathrm{G}$ & $11(16.9)$ & $5(7.6)$ & 2.6762 & .2624 & G & $13(10)$ & $7(5.3)$ & & & \\
\hline & $\mathrm{G} / \mathrm{G}$ & $1(1.5)$ & $1(1.5)$ & & & & & & & & \\
\hline \multicolumn{12}{|l|}{ TLR4 T399L } \\
\hline & $\mathrm{T} / \mathrm{T}$ & $60(92.3)$ & $59(89.4)$ & & & $\mathrm{T}$ & $125(96.2)$ & $124(93.9)$ & $1.613[0.513-5.066]$ & 0.6811 & .409 \\
\hline & $\mathrm{T} / \mathrm{I}$ & $5(7.7)$ & $6(9.1)$ & 1.0084 & .604 & I & $5(3.8)$ & $8(6.1)$ & & & \\
\hline & $\mathrm{I} / \mathrm{I}$ & $0(0)$ & $1(1.5)$ & & & & & & & & \\
\hline \multicolumn{12}{|l|}{ CD14 C-159T } \\
\hline & $\mathrm{C} / \mathrm{C}$ & $20(30.8)$ & $21(31.8)$ & & & C & $70(53.8)$ & $75(56.8)$ & $0.887[0.545-1.443]$ & 0.2341 & .628 \\
\hline & $\mathrm{C} / \mathrm{T}$ & $30(46.1)$ & $33(50)$ & 0.493 & .7815 & $\mathrm{~T}$ & $60(46.2)$ & $57(43.2)$ & & & \\
\hline & $\mathrm{T} / \mathrm{T}$ & $15(23.1)$ & $12(18.2)$ & & & & & & & & \\
\hline
\end{tabular}

$\mathrm{CI}$, confidence interval; OR, odds ratio; TLR, toll-like receptor.

Values are expressed as no. (\%).

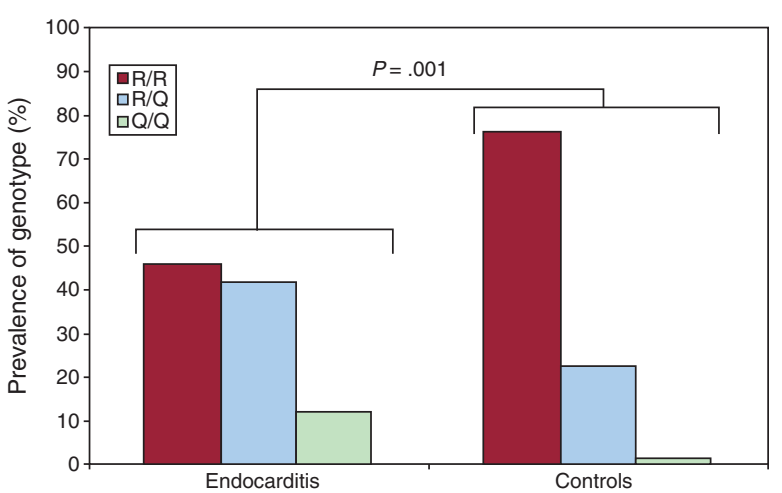

Figure 2. Prevalence of the genotypes corresponding to the endocarditis and control groups for the polymorphism toll-like receptor $2 \mathrm{R} 753 \mathrm{Q}$.

endocarditis phenotype (Table 2). All three genetic models were significant, the co-dominant one carrying the highest risk. For the recessive and co-dominant models the odds ratio (OR) for genotype effects on having infective endocarditis phenotype were 9.12 and 13.33 , respectively, while the OR of the dominant model was 3.65.

\section{DISCUSSION}

This is the first study to show that the TLR2 R753Q polymorphism is associated with a significant increased risk of infective endocarditis, and that co-dominant, recessive and dominant genotypes are associated with the infective endocarditis phenotype.

SNPs R677W $\mathrm{W}^{7}$ and $\mathrm{R} 753 \mathrm{Q}^{8}$ within the gene encoding TLR2 have previously been reported to carry a risk of infectious diseases.

The R753Q polymorphism was first identified by Lorenz et al. ${ }^{6} \mathrm{~A}$ positive association has also been reported with Mycobacterium tuberculosis and with acute rheumatic fever caused by Grampositive bacteria ( $\beta$-hemolytic Streptococcus). ${ }^{12}$ Previous studies are in concordance with our findings. On the other hand, in a study of 420 consecutive patients with severe $S$. aureus infection, Moore et al. found no association with this SNP. ${ }^{13}$

Regarding the TLR2 R677W SNP, no differences were observed in the distribution of the genotypes or alleles in our study. This is consistent with data in the literature, as this polymorphism has only been identified in Asian populations with lepromatous leprosy, and not in Caucasian European populations. ${ }^{7}$

In contrast, the SNPs TLR4 D299G and C-159T CD14 do have a positive association with several infectious diseases, such as septic shock due to Gram-negative bacteria. ${ }^{4,8,9}$ In our study, no positive correlation was found with infective endocarditis, perhaps because only $7.7 \%$ of the patients in our study had infective endocarditis due to Gram-negative bacteria.

In conclusion, we found that the polymorphism of the TLR2 R753Q leads to increased susceptibility to infective endocarditis. It is necessary to reproduce the study of population groups with different characteristics in order to prove the validity of the results and identify other genetic factors associated with an increased risk

Table 2

Logistic Regression Analysis of Toll-Like Receptor 2 R753Q Genetic Variants Associated With Infective Endocarditis (All Patients, $\mathrm{n}=131$ )

\begin{tabular}{|c|c|c|c|c|c|c|}
\hline \multirow[t]{2}{*}{ Genetic variant and reference SNP } & \multicolumn{2}{|c|}{ Recessive model } & \multicolumn{2}{|c|}{ Co-dominant model } & \multicolumn{2}{|c|}{ Dominant model } \\
\hline & OR $(95 \% \mathrm{CI})$ & $P$ value & OR $(95 \% \mathrm{CI})$ & $P$ value & OR $(95 \% \mathrm{CI})$ & $P$ value \\
\hline TLR2 R753Q & $9.12(1.11-75.18)$ & $.04^{\mathrm{a}}$ & $13.33(1.59-111.92)$ & $.017^{\mathrm{b}}$ & $3.65(1.73-7.69)$ & $.001^{\mathrm{c}}$ \\
\hline
\end{tabular}

$\mathrm{CI}$, confidence interval; OR, odds ratio; SNP, single nucleotide polymorphisms; TLR, toll-like receptor.

OR are presented for the highest-risk genotype as compared with the lowest-risk genotype.

The number of patients (131) reflects the genotypes available. Specific genotype comparisons are listed below.

a The values are for the comparison of the QQ genotype with the combined R/Q and RR genotypes.

b The values are for the comparison of the QQ genotype with RR genotype.

c The values are for the comparison of the combined R/Q and QQ genotypes with the RR genotype. 
of infective endocarditis, given the importance of the variability in their genetic make up.

\section{FUNDING}

This work was supported by the Gerencia de Salud, Consejería de Sanidad, Junta de Castilla y Leon [GRS 143/A/07], by Redes Temáticas, RD06/0001/0020 and by Obra Social Caja Burgos.

\section{CONFLICTS OF INTEREST}

None declared.

\section{REFERENCES}

1. King JW, Nguyen VQ Conrad SA. Results of a prospective statewide reporting system for infective endocarditis. Am J Med Sci. 1988;295:517-27.

2. San Román JA, López J, Vilacosta I, Luaces M, Sarriá C, Revilla A, et al. Prognostic stratification of patients with left-sided endocarditis determined at admission. Am J Med. 2007;120:369.e1-7.

3. Mylonakis E, Calderwood SB. Infective endocarditis in adults. N Engl J Med. 2001;345:1318-30.
4. Schröder NW, Schumann RR. Single nucleotide polymorphisms of Toll-like receptors and susceptibility to infectious disease. Lancet Infect Dis. 2005; 5:156-64.

5. Cook DN, Pisetsky DA, Schwartz DA. Toll-like receptors in the pathogenesis of human disease. Nat Immunol. 2004;5:975-9.

6. Lorenz E, Mira JP, Cornish KL, Arbour NC, Schwartz DA. A novel polymorphism in the toll-like receptor 2 gene and its potential association with staphylococcal infection. Infect Immun. 2000;68:6398-401.

7. Kang TJ, Chae GT. Detection of toll-like receptor 2 (TLR2) mutation in the lepromatous leprosy patients. FEMS Immunol Med Microbiol. 2001;31:53-8.

8. Agnese DM, Calvano JE, Hahm SJ, Coyle SM, Corbett SA, Calvano SM, et al. Human toll-like receptor 4 mutations but not CD14 polymorphisms are associated with an increased risk of Gram-negative infections. J Infect Dis. 2002;186:1522-5

9. Sutherland AM, Walley KR, Russell JA. Polymorphisms in CD14, mannosebinding lectin, and Toll-like receptor-2 are associated with increased prevalence of infection in critically ill adults. Crit Care Med. 2005;33:638-44.

10. Guo SW, Thompson EA. Performing the exact test of Hardy-Weinberg proportion for multiple alleles. Biometrics. 1992;48:361-72.

11. Drumm ML, Konstan MW, Schluchter MD, Handler A, Pace R, Zou F, et al.; Gene Modifier Study Group. Genetic modifiers of lung disease in cystic fibrosis. N Engl J Med. 2005;353:1443-53.

12. Berdeli A, Celik HA, Ozyürek R, Dogrusoz B, Aydin HH. TLR-2 gene Arg753Gln polymorphism is strongly associated with acute rheumatic fever in children. J Mol Med. 2005;83:535-41.

13. Moore CE, Segal S, Berendt AR, Hill AV, Day NP. Lack of association between Toll-like receptor 2 polymorphisms and susceptibility to severe disease caused by Staphylococcus aureus. Clin Diagn Lab Immunol. 2004;11: 1194-7. 